\title{
PRODUKSI DAN EVALUASI KUALITAS SUSU BUBUK ASAL KAMBING PERANAKAN ETTAWA (PE)
}

\author{
[Production and Quality Evaluation of Ettawa-Crossbred Goat Milk Powder]
}

\author{
Widodo*, Afina Viyunnur Rachmawati, Rina Chulaila dan I Gede Suparta Budisatria \\ Fakultas Peternakan, Universitas Gadjah Mada, Yogyakarta
}

Diterima 06 September 2011 / Disetujui 08 Juni 2012

\begin{abstract}
The objective of this study was to produce milk powder from Ettawa-crossbred goat milk and subsequently evaluate the quality of the products. The raw material used was Ettawa-crossbred goat fresh milk with total solid, lactose, fat, and protein content of 15.93\%, 4.2\%, 4.8\% and 4.7\%, respectively. Milk with final total solid of $17.5 \%$ and $20 \%$ were prepared for spray drying by adding skim milk powder. Drying was carried out using a spray dryer type Lamp having nozzle size of $0.05 \mathrm{~mm}$ with an inlet temperature of $90^{\circ} \mathrm{C}$ and an outlet temperature of $45^{\circ} \mathrm{C}$. Parameters observed were chemical, physical and microbiological qualities. The data showed that milk powder produced from Ettawa-crossbred goat milk had water content of 1.5-1.7\%. Further analysis showed that the acidity, proteins, lactose, and fat content were $0.90 \%, 28.4 \%, 21.7 \%$, and $22.5 \%$, respectively. The physical analysis showed that milk powder produced from Ettawa-crossbred goat milk had a higher wettability score (143 seconds) as compared to that of commercial products (29 seconds), a higher sieve test score ( $0.6 \mathrm{~g}$ vs $0.004 \mathrm{~g}$ ), but similar index of insolubility (1.4 $\mathrm{ml} v$ s. $1.6 \mathrm{ml}$ ). The microbiological analysis showed that the Total Plate Count (TPC), Enterobacteriaceae (EB) and presumptive coliforms increased during storage either in refrigerator or room temperature. The increase in TPC, EB and coliforms was substantially higher when products were kept at room temperature than in refrigerator. In conclusion, Ettawa-crossbred goat milk powder had a good nutrition quality, but still need improvement for the physicochemical characteristic including wettability and nutritional enrichment for vitamins and minerals by means of fortification.
\end{abstract}

Keywords: Ettawa-crossbred goats, milk powder, powder quality

\begin{abstract}
ABSTRAK
Penelitian ini bertujuan untuk memproduksi susu bubuk asal kambing PE dengan cara pengeringan semprot diikuti evaluasi kualitas produk yang dihasilkan. Bahan dasar yang digunakan adalah susu kambing PE dengan kadar padatan total $15,93 \%$, laktosa $4,2 \%$, lemak $4,8 \%$ dan protein $4,7 \%$. Padatan total untuk proses spary drying diatur pada kadar 17,5 dan $20 \%$ dengan penambahan susu bubuk skim. Pengeringan susu dilakukan dengan spray dryer tipe Lamp dengan nozzle $0,05 \mathrm{~mm}$ dan menggunakan suhu inlet $90^{\circ} \mathrm{C}$ dan outlet $45^{\circ} \mathrm{C}$. Parameter yang diamati adalah kualitas kimia, fisik dan mikrobiologis. Hasil penelitian menunjukkan bahwa susu bubuk asal kambing PE mempunyai kadar air 1,5 - 1,7\%. Analisa lanjut menunjukkan kadar keasaman, protein, laktosa dan lemak secara berturutan adalah $0,90 \% ; 28,4 \% ; 21,7 \%$; dan $22,5 \%$. Hasil analisis kualitas fisik menunjukkan susu bubuk asal kambing PE mempunyai wettability yang lebih lama (143 detik) dibandingkan dengan susu bubuk komersial (29 detik), angka sieve test yang lebih tinggi (0,6 vs 0,004 g) dengan indeks ketidaklarutan yang sama (1,4 $\mathrm{ml} v \mathrm{~s} 1,6 \mathrm{ml})$. Uji mikrobiologis susu bubuk menunjukkan angka Total Plate Count (TPC), Enterobacteriaceae (EB) dan koliform meningkat selama penyimpanan baik suhu ruang maupun suhu refrigerator. Peningkatan angka TPC, EB dan koliform terjadi lebih cepat ketika produk disimpan pada suhu ruang dibandingkan pada refrigerator. Sebagai kesimpulan, susu bubuk asal kambing PE memiliki kualitas nutrisi yang cukup baik walaupun masih perlu peningkatan kualitas fisik khususnya wettability dan peningkatan nutrisi khususnya vitamin dan mineral.
\end{abstract}

Kata kunci: Kambing Peranakan Ettawa, susu bubuk, kualitas fisiko-kimia

\section{PENDAHULUAN}

Kambing Peranakan Ettawa (PE) mempunyai peran ganda sebagai kambing penghasil susu dan daging (Pribadiningtyas et al., 2012; Sutama et al., 2012). Menurut Knights dan Garcia (1997), kambing PE mampu memproduksi susu sebesar 0,9 $\mathrm{kg} /$ hari/ekor. Komposisi utama susu kambing PE terdiri atas laktosa $(4,27 \%)$, protein $(3,52 \%)$, lemak $(4,25 \%)$ dengan padatan total berkisar antara 13 sampai $14 \%$ (Marwah et al., 2010; Sukarini, 2006). Selain bergizi tinggi, susu kambing PE

*Korespondensi Penulis :

E-mail : widodohs@ugm.ac.id juga berkhasiat untuk penyembuhan berbagai penyakit seperti asma dan TBC (Moelyanto dan Wiryanta, 2002). Susu kambing PE mempunyai ukuran globula lemak kecil dengan proporsi asam lemak rantai pendek lebih banyak sehingga mudah diserap tubuh serta efek laksatif protein yang rendah sehingga tidak menyebabkan diare. Sebagai produk pangan kaya nutrisi, susu kambing PE mudah mengalami kerusakan yang disebabkan oleh cemaran mikrobia dan berpotensi terjadinya penyakit terbawa-pangan (foodborne-diseases) (Suguna et al., 2012; Van Kessel et al., 2011; LeJeune dan Rajala-Schultz, 2009; Oliver et al., 2009; Adesiyun et al., 2007; Kagkli et al., 2007; Straley et al., 2006; Oliver et al., 2005; Yagoub et al., 2005). Berbagai proses pengolahan susu dilakukan utamanya 
untuk pengawetan dan juga untuk meningkatkan efisiensi dan efektivitas penyimpanan. Di antara proses pengolahan susu tersebut, salah satunya adalah pembuatan susu bubuk dengan metode pengeringan (Widodo, 2003). Proses pembuatan susu bubuk merupakan salah satu contoh pengolahan susu dengan tujuan menurunkan kadar air susu dengan cara pengeringan semprot (spray drying). Proses pengeringan ini melibatkan evaporasi diikuti dengan spray drying sehingga dihasilkan susu bubuk kering dengan aktivitas air (aw) rendah, sekitar 0,2 (Anonim, 2011). Aktivitas air $\left(\mathrm{a}_{\mathrm{w}}\right)$ adalah kandungan air dalam pangan yang mampu dimanfaatkan untuk pertumbuhan mikrobia, sehingga aw yang rendah pada produk susu bubuk menghambat pertumbuhan mikrobia perusak dan patogen (de Goffau et al., 2011). Pembuatan susu bubuk juga menurunkan kuantitas air sehingga produk susu olahan dapat disimpan secara efisien dalam jangka waktu lama tanpa terjadi penurunan kualitas (awet). Dalam bentuk bubuk kering, volume dan berat susu berkurang sehingga menurunkan biaya transportasi dan penyimpanan. Tujuan penelitian ini adalah menghasilkan atau memproduksi susu bubuk kambing PE dan evaluasi kualitas susu bubuk yang dihasilkan. Dalam penelitian ini juga dikaji pengaruh padatan total awal terhadap kadar air susu bubuk yang dihasilkan.

\section{BAHAN DAN METODE}

\section{Bahan}

Bahan yang digunakan dalam penelitian ini meliputi susu kambing PE, diperoleh dari peternakan kambing $P E$ di Yogyakarta, susu bubuk skim, MRS agar (oxoid), MRS broth (oxoid), aquades, kalium lodida (KI) $10 \%, \mathrm{HCl} 2 \mathrm{~N}$, gliserol, sukrosa, $\mathrm{H}_{2} \mathrm{SO}_{4}$ pekat, $\mathrm{Na}_{2} \mathrm{~S}_{2} \mathrm{O}_{3}, \mathrm{ZnSO}_{4}, \mathrm{NaOH} 0,75 \mathrm{~N}, \mathrm{NaOH}$ $0,1 \mathrm{~N}$, metilen biru $0,02 \%$, indikator PP $1 \%$, Chloramine-T, katalis, dan batu didih.

\section{Pengujian susu segar dan standarisasi}

Pengujian susu segar meliputi uji pH, keasaman, kadar air, lemak, protein, laktosa, padatan total (TS) dan uji mikrobiologis susu segar. Uji pH dengan metode potensiometer menggunakan pH meter (Hadiwiyoto, 1994). Uji kadar laktosa ditentukan dengan cara titrasi kadar laktosa dalam filtrat (Sudarmadji et al., 1984). Pengujian kadar protein dilakukan melalui penentuan $N$ total cara makro Kjeldahl yang dimodifikasi (Sudarmadji et al., 1984). Pengujian kadar lemak menggunakan metode Babcock (Sudarmadji et al., 1984). Untuk mengetahui tingkat cemaran mikrobia pada susu segar dilakukan uji Methylen Blue Reduction Time (MBRT) dan uji keasaman dilakukan menurut metode Mann's Acid Test (Hadiwiyoto, 1994). Standarisasi susu dilakukan dengan penambahan susu bubuk skim sehingga didapatkan padatan total awal 17,5 dan $20 \%$.

\section{Evaporasi dan spray drying}

Evaporasi dan spray drying dilakukan dalam skala laboratorium dengan alat spray drier tipe Lamp dengan nozzle ukuran $0,05 \mathrm{~mm}$ pada suhu inlet $90^{\circ} \mathrm{C}$ dan outlet $45^{\circ} \mathrm{C}$. Susu segar asal kambing PE disiapkan dengan penambahan susu bubuk skim sehingga didapatkan padatan total awal 17,5 dan
$20 \%$. Susu segar dengan total solid 17,5 dan $20 \%$ ini kemudian dipasteurisasi pada suhu $78^{\circ} \mathrm{C}$ selama 15 detik, dilanjutkan dengan spray drying. Spray drying dilakukan dengan menyemprotkan suspensi sampel susu melalui nozzle (atomizer) sehingga diperoleh bubuk susu (powder) dalam bentuk butiran kecil.

\section{Evaluasi kualitas produk akhir susu bubuk}

Susu bubuk hasil spray drying dikumpulkan dalam plastik steril dan disimpan pada suhu ruang dan refrigerator selama 4 minggu untuk analisa kualitas fisik, kimia, dan mikrobiologi. Analisa kualitas fisik meliputi wettability, indeks ketidaklarutan (insolubility index), dan indeks cemaran (impurities) menggunakan sieving test method (AOAC, 1990). Pengujian kadar air menggunakan metode AOAC (Sudarmadji et al., 1984). Kualitas kimia yang diuji meliputi kadar lemak, protein, laktosa dan keasaman (Sudarmadji et al., 1984; Hadiwiyoto, 1994). Kualitas mikrobiologis susu bubuk meliputi Total Plate Count (TPC), uji penduga coliform, dan enterobacteriaceae (EB). Uji TPC dilakukan dengan metode penghitungan koloni (indirect counting) pada media total mikroba (Plate Count Agar (PCA)). Penghitungan EB dilakukan dengan medium Violet Red Bile Glucose (VRBG), untuk uji penduga coliform menggunakan metode Most Probable Number (MPN) dengan tiga seri pengenceran (Blodgett, 2010).

\section{Analisa statistik}

Rancangan acak lengkap (RAL) pola searah dengan 2 perlakuan digunakan untuk analisa statistik kualitas fisik dan kimia susu bubuk (Astuti, 1981). Pengaruh perbedaan kadar total solid terhadap kadar air diuji dengan paired sample T-Test dengan dua perlakuan (total solid 17,5 dan $20 \%$ ) dan masing masing tiga ulangan.

\section{HASIL DAN PEMBAHASAN}

\section{Kualitas susu segar kambing PE}

Kambing PE dikenal sebagai kambing penghasil susu disamping juga sebagai sumber daging. Menurut Sutama et al. (2012), rerata produksi susu kambing PE adalah 922 g/hari/ekor dengan masa laktasi 170 hari. Puncak produksi susu kambing PE dicapai 6 sampai 8 minggu setelah beranak, dan mencapai produksi konstan selama 3 bulan sebelum akhirnya berkurang dengan laju 3,5\% per minggu. Tabel 1 menunjukkan hasil uji kualitas kimia (nutrisi) susu segar kambing PE dibandingkan dengan susu sapi dan susu kambing lainnya (goat milk).

Analisa kualitas susu segar menunjukkan bahwa susu kambing PE mempunyai kadar TS 15,9\%. Kadar TS susu kambing ini lebih tinggi dibandingkan TS susu sapi yaitu antara 11 sampai 13\% (Park et al., 2007) dan total solid susu kambing lainnya yaitu $12,7 \%$ (Park et al., 2007). Kadar protein dan lemak susu kambing PE lebih tinggi dibandingkan kadar protein dan lemak susu sapi dan susu kambing lainnya, namun kadar laktosa susu kambing PE lebih rendah dibandingkan susu sapi (Tabel 1). Kadar lemak, berat jenis dan pH susu kambing PE yang dilaporkan ini sesuai dengan kualitas susu kambing PE yang diberi ransum hijauan (Sukarini, 2012), namun kadar 
protein $4,7 \%$ pada susu kambing $P E$ ini lebih tinggi dibandingkan kadar protein $3,6 \%$ pada susu kambing PE yang diberi pakan ransum campuran antara hijauan (70\%) dan konsentrat $(30 \%)$. Kadar protein susu kambing PE ini sama dengan kadar protein susu kambing PE yang diberi suplementasi protein terproteksi dalam wafer pakan komplet (Utari et al., 2012). Kualitas mikrobiologis susu segar asal kambing PE dianalisa menggunakan uji MBRT. Uji MBRT adalah penghitungan waktu (jam) yang dibutuhkan untuk menghilangkan warna biru methylen blue yang ditambahkan (1\%) ke dalam susu segar, dan ini sangat terkait dengan pertumbuhan dan aktivitas mikrobia untuk mengkonsumsi oksigen terlarut dalam susu segar sehingga menurunkan potensi reduksi-oksidasi pada susu segar (Chatterjee et al., 2006). Semakin cepat waktu (<2 jam) yang dibutuhkan untuk menetralkan warna biru, semakin buruk kualitas mikrobiologis susu segar (Anderson et al., 2011). Menurut Standar Nasional Indonesia (2006), susu segar yang baik harus mempunyai nilai uji MBRT berkisar 2 sampai 5 jam. Pada penelitian ini, uji MBRT susu segar asal kambing PE membutuhkan waktu 4 jam, yang berarti kualitas mikrobiologis susu cukup bagus menurut Anderson et al. (2011) dan masih memenuhi standar SNI.

Tabel 1. Rerata kadar nutrisi susu segar asal kambing PE susu sapi dan kambing

\begin{tabular}{lccc}
\multicolumn{2}{c}{ dan kambing } & & \\
\hline \multicolumn{1}{c}{ Parameter Kualitas } & Hasil ${ }^{1}$ ) & Susu Sapi $\left.{ }^{2}\right)$ & Susu Kambing ${ }^{3}$ \\
\hline Berat jenis (kg/l) & $1,03 \pm 0,002$ & $1,023-1,039$ & $1,029-1,039$ \\
pH & $6,56 \pm 0,012$ & $6,65-6,71$ & $6,50-6,80$ \\
Derajat keasaman & $0,24 \pm 0,007$ & $0,22-0,25$ & $0,14-0,23$ \\
(\% asam laktat) & & & \\
Uji Methylen Blue & $4,0 \pm 0,0$ & $2,0-5,0$ & - \\
Reduction Time & & & \\
(jam) & & & \\
Kadar protein (\%) & $4,7 \pm 0,017$ & 3,2 & 3,4 \\
Kadar lemak (\%) & $4,8 \pm 0,47$ & 3,6 & 3,8 \\
Kadar laktosa (\%) & $4,24 \pm 0,08$ & 4,7 & 4,1 \\
Kadar air (\%) & $84,07 \pm 0,36$ & 87,4 & 87,3 \\
Total solid (\%) & 15,93 & 12,6 & 12,7 \\
\hline
\end{tabular}

Keterangan:

1)Data hasil penelitian ini

2)Data pembanding dari susu sapi (Park et al., 2007)

3)Data pembanding dari susu kambing (Park et al., 2007)

\section{Produksi susu bubuk}

Studi awal produksi susu bubuk dilakukan untuk menentukan kadar TS optimum dari susu segar yang akan diproses menjadi susu bubuk. Atas dasar analisa awal susu segar kambing PE, maka ditentukan pemilihan kadar TS 17,5\% dan kadar TS 20\% dipakai sebagai kadar TS awal dalam pembuatan susu bubuk kambing PE. Produksi susu bubuk asal kambing PE dilakukan dengan menggunakan spray drier pada suhu inlet $90^{\circ} \mathrm{C}$ dan suhu outlet $45^{\circ} \mathrm{C}$. Karena tingkat keawetan bahan pangan sangat ditentukan oleh kadar air, maka kadar air susu bubuk yang diperoleh dijadikan acuan utama kualitas fisik dan kimia dari produk susu bubuk yang dihasilkan. Hasil analisa kadar air susu bubuk yang dihasilkan ditampilkan pada Tabel 2.

Tabel 2 menunjukkan bahwa kadar total solid awal 17,5\% dan 20\% pada susu PE yang dikaji tidak berpengaruh terhadap kadar air pada produk akhir susu bubuk. Hasil analisis menunjukkan bahwa susu bubuk asal kambing PE mempunyai kadar air yang tidak berbeda nyata, yaitu 1,70\% dan 1,5\% untuk susu dengan TS awal 17,5\% dan 20\%. Standar Nasional Indonesia (2006) mensyaratkan kadar air maksimal 5\% (w/w) pada susu bubuk. Kadar air rendah hasil pengeringan semprot merupakan salah satu penyebab rendahnya aktivitas air $\left(a_{w}\right)$ sehingga menghambat pertumbuhan mikrobia perusak susu. Pertumbuhan bakteri berhenti pada aw 0,75 sedangkan khamir dan jamur berhenti pada aw 0,65 (de Goffau et al., 2011). Susu bubuk penuh dengan kadar $a_{w} 0,3$ mempunyai daya simpan antara 0,5 sampai 2 tahun ketika dikemas dalam kondisi vakum dan kedap udara. Karena kadar air susu bubuk tidak terpengaruh oleh kadar total solid awal susu segar, maka kadar total solid $17,5 \%$ untuk dasar pembuatan susu bubuk pada tahap penelitian selanjutnya.

Tabel 2. Kadar air dari susu bubuk asal kambing PE pada kadar total solid 17,5 dan $20 \%$

\begin{tabular}{|c|c|c|}
\hline & Kadar TS 17,5\% & Kadar TS $20 \%$ \\
\hline Kadar air (\%) & $1,70 \pm 0,5^{\text {ns }}$ & $1,51 \pm 0,3^{\text {ns }}$ \\
\hline
\end{tabular}

\section{Kualitas fisik susu bubuk}

Kualitas fisik susu bubuk asal kambing PE yang diamati meliputi Wettability, Sieve test dan Insolubility Index. Salah satu parameter susu bubuk yang menentukan kualitas fisik adalah kemampuan dan kecepatan susu bubuk untuk terdispersi dalam air (wettability). Semakin cepat kemampuan terdispersi dalam air, semakin baik pula kualitas fisik dari susu bubuk tersebut. Hal ini penting mengingat produk susu bubuk biasanya disuspensikan dalam air sebelum dikonsumsi. Kemampuan untuk menyerap air dan membentuk suspensi homogen secara cepat merupakan indikator kualitas fisiko-kimia susu bubuk yang bagus (Widodo, 2003). Sebaliknya, ketidakmampuan menyerap air dan larut biasanya disebabkan oleh adanya kandungan lemak susu yang sifatnya non polar. Tabel 3 berikut menunjukkan wettability, sieve test dan insolubility index dari susu bubuk yang dihasilkan dari susu kambing PE.

Tabel 3. Perbandingan wettability, sieve test dan insolubility index susu bubuk kambing PE dan susu komersial asal sapi

\begin{tabular}{|c|c|c|}
\hline Kualitas Fisik & $\begin{array}{c}\text { Susu Bubuk Asal } \\
\text { Kambing PE }\end{array}$ & $\begin{array}{c}\text { Susu Bubuk Komersial } \\
\text { Asal Sapi }\end{array}$ \\
\hline Wettability (detik) & $143,3 \pm 38,9^{a}$ & $28.9 \pm 4,4^{b}$ \\
\hline Sieve test (gram) & $0,59 \pm 0,21 c$ & $0,04 \pm 0,01^{d}$ \\
\hline Insolubility index (ml) & $1,64 \pm 0,14$ & $1,38 \pm 0,10$ \\
\hline
\end{tabular}

Tabel 3 menunjukkan perbedaan wettability antara produk susu bubuk komersial asal susu sapi dengan susu bubuk asal kambing PE. Perbedaan wettability ini disebabkan oleh susu kambing mempunyai kadar lemak lebih tinggi dibandingkan susu sapi yang dipakai sebagai bahan dasar pembuatan susu bubuk komersial (Utari et al., 2012; Park et al., 2007). Pada sisi lain, wettability susu bubuk komersial disebabkan oleh adanya proses emulsifikasi dengan penambahan lesitin (Widodo, 2003). Dalam penelitian ini, penambahan lesitin pada susu bubuk asal kambing PE tidak dilakukan dengan maksud untuk mengetahui kemampuan wettability susu bubuk asal kambing PE secara 
alami. Lesitin adalah suatu contoh emulsifier yang mampu menstabilkan emulsi air dalam lemak atau lemak dalam air, sehingga dimungkinkan terbentuk suatu dispersi fase lemak yang merata pada suatu fase air. Pada proses pembuatan susu bubuk, lesitin ditambahkan untuk menghasilkan susu bubuk instan yang mampu larut dan terdispersi merata pada air baik pada suhu dingin atau panas. Parameter kualitas fisik susu bubuk yang juga perlu diuji adalah tingkat cemaran (impurities) dengan sieve test. Sieve test dilakukan untuk mengukur tingkat cemaran fisik susu bubuk berupa susu yang menggumpal atau gosong selama pemanasan.

Hasil sieve test pada Tabel 3 menunjukkan bahwa susu bubuk asal kambing PE mempunyai tingkat cemaran partikel asing lebih tinggi $(0,59 \mathrm{~g})$ dibandingkan dengan susu bubuk komersial $(0,04 \mathrm{~g})$. Sumber partikel cemaran ini adalah hasil pemanasan tidak sempurna yang berakibat pada terbentuknya gumpalan susu yang mengeras. Erdam dan Yuksel (2005) melaporkan bahwa protein whey khususnya $\beta$-lactoglobulin dan a-lactalbumin dalam susu sangat sensitif terhadap pemanasan. Protein whey $\beta$-lactoglobulin mempunyai gugus sulfhydril bebas dan ikatan disulfida yang memungkinkan terbentuknya polimer melalui ikatan dengan sesama $\beta$-lactoglobulin atau antara $\beta$ lactoglobulin dengan protein lain (Miyamoto et al., 2009; Cho et al., 2003). Beberapa penelitian telah melaporkan adanya denaturasi protein whey pada pemanasan diatas suhu $60^{\circ} \mathrm{C}$, dan terjadinya interaksi sesama protein whey atau dengan $k$ kasein membentuk gumpalan (Anema dan Li, 2003a; Anema dan Li, 2003b; Guyomarc'h et al., 2003). Selain faktor pemanasan, tidak adanya bahan pengemulsi (emulsifier) menyebabkan kualitas fisik susu bubuk tidak selembut susu komersial. Gambar 1 menunjukkan perbedaan sieve test antara susu bubuk komersial dan susu bubuk kambing PE. Gambar 1 secara jelas menunjukkan bahwa susu bubuk komersial mempunyai struktur fisik yang lebih halus dan sedikit gumpalan sehingga lolos dari kertas saring berdiameter $2 \mathrm{~mm}$.
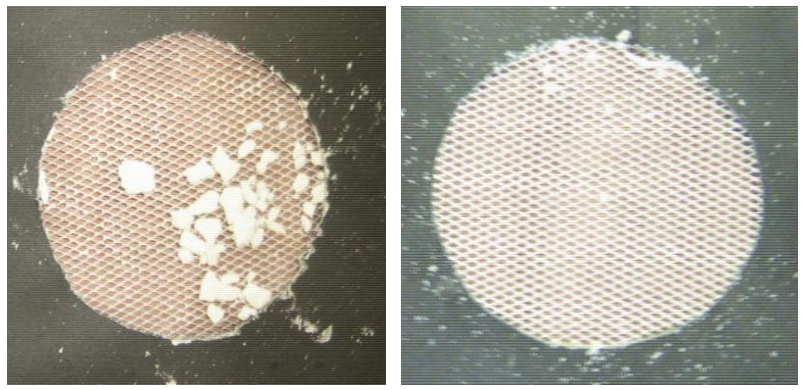

Susu Bubuk asal Kambing PE Susu Bubuk Komersial asal Sapi

Gambar 1. Hasil uji sieve test pada susu bubuk kambing PE dan susu komersial asal sapi

Insolubility Index menunjukkan banyak sedikitnya partikel tidak larut hasil denaturasi protein yang terjadi selama proses pemanasan dan pengolahan susu (Widodo, 2003). Hasil uj insolubility index menunjukkan bahwa insolubility index susu bubuk kambing $(1,38 \mathrm{ml})$ tidak berbeda nyata jika dibandingkan dengan susu bubuk komersial $(1,64 \mathrm{ml})$ (Tabel 3$)$. Menurut Widodo (2003), tinggi rendahnya kelarutan susu bubuk selain ditentukan oleh komposisi bahan yang ditambahkan, juga di- pengaruhi oleh proses pengolahan. Kondisi pengeringan yang tidak sempurna dan tingginya suhu udara pengering akan berakibat pada tingginya insolubility (bagian protein yang tidak larut) dari produk yang dihasilkan (U. S Dairy Export Council, 2001 cit Khalid et al., 2009).

\section{Kualitas kimia}

Uji kualitas kimia susu bubuk asal kambing PE yang dilakukan meliputi uji kadar protein, lemak dan laktosa serta tingkat keasaman susu bubuk. Hasil uji kualitas kimia susu bubuk asal kambing PE dapat dilihat dari Tabel 4.

Tabel 4. Kualitas kimia susu bubuk asal kambing PE dan susu bubuk komersial asal sapi

\begin{tabular}{lcc}
\hline $\begin{array}{c}\text { Kualitas Kimia Susu } \\
\text { Bubuk }\end{array}$ & $\begin{array}{c}\text { Susu Bubuk } \\
\text { Kambing PE }\end{array}$ & $\begin{array}{c}\text { Susu Bubuk Komersial } \\
\text { asal Sapi }\end{array}$ \\
\hline Kadar protein (\%) & $28,4 \pm 0,04$ & $28,2 \pm 0,55$ \\
Kadar lemak (\%) & $22,5 \pm 0,06^{\mathrm{a}}$ & $28,5 \pm 0,01^{\mathrm{b}}$ \\
Kadar laktosa (\%) & $21,7 \pm 0,23 \mathrm{c}$ & $26,9 \pm 2,5^{\mathrm{d}}$ \\
Derajat keasaman (\%) & $0,90 \pm 0,01$ & $0,91 \pm 0,03$
\end{tabular}

Keterangan: superskrip berbeda pada baris yang sama menunjukkan signifikansi nyata $(P \leq 0,05)$

Tabel 4 menunjukkan bahwa kadar protein susu bubuk asal kambing PE masih dalam kisaran kadar protein susu komersial asal sapi. Badan Standarisasi Nasional (2006) menyatakan kadar protein (b/b) susu bubuk berlemak minimal $23 \%$ dan susu bubuk tanpa lemak minimal $30 \%$. Perhitungan lanjut kadar protein berbasis berat kering (bk) bahan padatan menunjukkan kadar protein susu bubuk tidak berbeda nyata dengan kadar protein pada susu segar, yaitu berkisar $4,8 \%$ bk sampai $5,0 \%$ bk. Hal ini menandakan bahwa perlakuan pengeringan dengan menggunakan suhu inlet $90^{\circ} \mathrm{C}$ dan outlet $45^{\circ} \mathrm{C}$ tidak berpengaruh terhadap kadar protein susu bubuk kambing PE. Menurut Zittle (1969), pada $\mathrm{pH}$ netral protein $k$-kasein stabil terhadap pemanasan suhu $100^{\circ} \mathrm{C}$ selama 5 menit. Lebih lanjut dijelaskan bahwa presipitasi protein $k$-kasein karena pemanasan suhu $100^{\circ} \mathrm{C}$ terjadi ketika susu mengandung garam $\mathrm{NaCl}$ (0,05 mM) dan $\mathrm{CaCl}_{2}$ (0,01 M) (Zittle, 1969). Dampak langsung proses pemanasan terhadap protein susu adalah denaturasi protein whey yang kemudian menyelimuti kasein dan membentuk agregat dengan misel kasein (Anema dan Li, 2003a; Vasbinder dan de Kruif, 2003). Tabel 4 menunjukkan bahwa kadar lemak susu bubuk kambing PE adalah $22,5 \%$ yaitu lebih rendah dari kadar lemak susu bubuk komersial asal sapi. Dengan kadar lemak $22,5 \%$, maka susu bubuk yang dihasilkan memenuhi kriteria sebagai susu bubuk kurang lemak (BSN, 2006). Khalid et al. (2009) melaporkan kualifikasi susu bubuk dalam tiga jenis, yaitu susu full cream (lemak 26\%), susu mengandung sebagian skim (partially skmmed) (lemak 8 sampai $24 \%$ ) dan susu skim (skimmed) (lemak 1,5\%). Badan Standarisasi Nasional (2006) menyatakan bahwa kandungan lemak (b/b) pada mutu susu bubuk berlemak adalah minimal $26 \%$ dan susu bubuk tanpa lemak maksimal $1,5 \%$. Tingginya kadar lemak pada susu bubuk komersial asal sapi dibandingkan susu bubuk kambing PE karena pada susu bubuk komersial biasanya dilakukan penam-bahan butter oil yang $100 \%$ tersusun atas lemak (Widodo, 2003). Penambahan butter oil dilakukan dengan tujuan peningkatan kadar lemak produk susu bubuk 
akhir. Pada sisi lain, rendahnya kadar lemak susu bubuk asal kambing PE terjadi karena adanya penambahan susu skim. Lemak merupakan penyusun yang penting dari susu karena mempunyai nilai gizi tinggi berdasar kalori yang dikandungnya, selain itu lemak juga mengandung banyak vitamin-vitamin dan asam-asam lemak esensial.

Laktosa merupakan sumber energi utama dalam produk susu. Dalam proses fermentasi menggunakan Bakteri Asam Laktat (BAL), biasanya laktosa dipecah menjadi glukosa dan galaktosa oleh enzim $\beta$-D-galactosidase (laktase). Namun demikian dalam proses pengolahan susu bubuk, kadar laktosa tidak mengalami perubahan karena memang tidak terjadi degradasi laktosa secara enzimatis. Tabel 4 menunjukkan bahwa kadar laktosa susu bubuk asal kambing PE lebih rendah dibandingkan dengan kadar laktosa susu bubuk komersial selaras dengan sifat asal komposisi kimia susu PE segar. Menurut Badan Standarisasi Nasional (2006), syarat mutu laktosa (b/b) pada susu bubuk berlemak adalah $26 \%$ dan susu bubuk tanpa lemak minimal $47 \%$. Keasaman susu sangat berkaitan dengan nilai $\mathrm{pH}$. Keasaman susu yang tinggi berakibat pada $\mathrm{pH}$ susu yang rendah, demikian sebaliknya. Tabel 4 menunjukkan bahwa kadar keasaman susu bubuk kambing PE adalah $0,90 \%$, dan keasaman susu bubuk asal kambing PE ini masih dalam kisaran tingkat keasaman susu bubuk komersial.

\section{Kualitas mikrobiologis}

Total mikroba (TPC) dihitung pada medium agar non-selektif setelah inkubasi pada suhu $30^{\circ} \mathrm{C}$ selama $2-3$ hari dalam kondisi aerob. Dengan demikian semua mikrobia pada susu yang bersifat aerob dan mesofilik akan tumbuh, seperti bakteri, spora bakteri dan fungi (yeast dan kapang). Sebaliknya, mikrobia anaerob seperti Clostridium dan yang optimum pada suhu dingin (psikrofilik) tidak akan tumbuh. Hasil uji TPC dan EB pada susu bubuk kambing PE disajikan pada Tabel 5 .

Tabel 5 menunjukkan angka TPC $1,9 \times 10^{3} \mathrm{CFU} / \mathrm{g}$ pada susu bubuk kambing PE hasil spray drying sebelum penyimpanan. Standar Nasional Indonesia (2006) mensyaratkan angka TPC maksimal $5 \times 10^{5} \mathrm{CFU} / \mathrm{g}$ untuk memenuhi syarat mutu susu bubuk. Dengan demikian angka TPC produk susu bubuk kambing PE memenuhi syarat kualitas SNI. Angka TPC dalam produk susu bubuk kambing PE ini sama dengan angka TPC pada susu formula untuk anak usia dibawah 2 tahun dan susu bubuk lainnya yang beredar di Pakistan (Rajput et al., 2009a; Rajput et al., 2009b). Selama penyimpanan, baik pada suhu ruang dan refrigerator, terjadi peningkatan angka TPC (Tabel 5) dengan angka TPC lebih tinggi diperoleh pada penyimpanan suhu ruang dibandingkan suhu refrigerator. Peningkatan angka TPC selama penyimpanan juga ditemui pada produk susu UHT yang disimpan pada suhu $4^{\circ} \mathrm{C}, 25^{\circ} \mathrm{C}$ dan $35^{\circ} \mathrm{C}$ selama 60 hari (Abid et al., 2009) dan susu homogenisasi yang disimpan suhu $4^{\circ} \mathrm{C}$ selama 14 hari (Smiddy et al., 2007). Tingginya angka TPC pada penyimpanan suhu ruang dapat dipahami mengingat TPC menghitung mikrobia aerobik mesofilik yang pertumbuhannya optimum pada suhu ruang dibandingkan pada suhu refrigerator. Angka TPC susu bubuk setelah penyimpanan pada suhu ruang adalah $19 \times 10^{4}$ CFU/g dan pada suhu refrigerator adalah $7,7 \times 10^{4} \mathrm{CFU} / \mathrm{g}$. Angka ini meningkat setelah penyimpanan minggu keempat menjadi $3,1 \times 10^{5} \mathrm{CFU} / \mathrm{g}$ pada suhu ruang dan $1,7 \times 10^{5} \mathrm{CFU} / \mathrm{g}$ pada suhu refrigerator. Secara umum angka TPC hanya menunjukkan jumlah mikrobia yang ada pada produk susu bubuk, tetapi tidak banyak memberikan informasi tentang jenis mikrobia apa saja yang tumbuh dan dari mana asalnya. Angka TPC berkaitan dengan kualitas bahan baku untuk proses produksi, tetapi bukan indikator utama kualitas higiene dan keamanan produk. Untuk dapat dipakai sebagai evaluasi higiene atau kualitas produk susu bubuk, uji TPC perlu dilengkapi dengan uji Enterobacteriaceae (EB) dan uji coliforms.

Enterobacteriaceae (EB) merupakan istilah dari bahasa Latin yang berarti bakteri dari intestin. Walaupun penamaannya mengindikasikan kelompok bakteri ini berasal dari sistem pencernaan manusia atau hewan, sebagian besar dari EB bebas hidup di alam. Kemampuan EB tahan terhadap kondisi lingkungan yang kering dijadikan dasar sebagai mikrobia indikator kualitas sanitasi lingkungan proses produksi bahan pangan. Hasil uji EB pada susu bubuk kambing PE dapat dilihat pada Tabel 5 . Tabel 5 menunjukkan kontaminasi EB yang cukup tinggi yaitu $1,5 \times 10^{3} \mathrm{CFU} / \mathrm{g}$. Angka EB dalam penelitian ini lebih tinggi daripada angka EB pada industri pengolahan susu yang berkisar antara 100 sampai $500 \mathrm{CFU} / \mathrm{g}$, dan lebih tinggi dari angka EB pada susu formula untuk anak usia dibawah 2 tahun di Pakistan yang jumlahnya kurang dari 5 CFU/g (Rajput et al., 2009b). Angka EB tinggi berarti tingkat sanitasi bahan baku dan proses produksi rendah dan berakibat pada angka TPC yang tinggi yaitu $1,9 \times 10^{3} \mathrm{CFU} / \mathrm{g}$ pada produk susu bubuk (Tabel 5). Semakin tinggi angka EB selama penyimpanan berimbas pada semakin tingginya angka TPC (Tabel 5). Jadi dapat dikatakan angka EB sangat berkaitan dengan angka TPC.

Tabel 5. Angka total mikroba (TPC) dan Enterobacteriaceae (EB) susu bubuk asal kambing PE disimpan pada suhu ruang dan refrigerator

\begin{tabular}{lccc}
\hline \multicolumn{1}{c}{ Sampel } & Pengujian & $\begin{array}{c}\text { Suhu } \\
\text { Ruang }\end{array}$ & $\begin{array}{c}\text { Suhu } \\
\text { Refrigerator }\end{array}$ \\
\hline Susu bubuk awal & TPC (CFU/g) & $1,9 \times 10^{3}$ & $1,9 \times 10^{3}$ \\
& EB (CFU/g) & $1,5 \times 10^{3}$ & $1,5 \times 10^{3}$ \\
Penyimpanan & TPC (CFU/g) & $19 \times 10^{4}$ & $7,7 \times 10^{4}$ \\
Minggu ke-1 & EB (CFU/g) & $3,8 \times 10^{4}$ & $2,0 \times 10^{4}$ \\
Penyimpanan & TPC (CFU/g) & $3,1 \times 10^{5}$ & $1,7 \times 10^{5}$ \\
Minggu ke-4 & EB (CFU/g) & $2,1 \times 10^{6}$ & $3,8 \times 10^{5}$ \\
\hline
\end{tabular}

Keterangan: data diperoleh dari 2 ulangan

Coliforms mempunyai arti "mirip dengan bakteri E. Coli". Coliforms merupakan kelompok bakteri Gram negatif yang sebagian besar merupakan bagian dari kelompok lebih besar yang disebut Enterobacteriaceae (EB) (Salman dan Hamad, 2011). Sifat khusus dari coliforms adalah kemampuannya memfermentasi laktosa dan menghasilkan gas. Karena kemiripannya dengan $E$. Coli, maka coliforms dipakai untuk memprediksi keberadaan $E$. Coli dan mikrobia patogen lainnya (El-zubeir dan Ahmed, 2007). Uji coliforms biasanya dilakukan dengan dua tahapan yaitu uji penduga dilajutkan uji penguat coliforms pada media Levine Eosin Methylene Blue (L-EMB (Salman dan Hamad, 2011; Shojaei dan Yadollahi, 2008). Uji penduga 
coliforms dilakukan dengan metode MPN dengan tiga seri pengenceran (Blodgett, 2010). dan hasilnya disajikan pada Tabel 6.

Tabel 6. MPN produk susu kambing PE sebelum dan sesudah penyimpanan

\begin{tabular}{ccccc}
\hline Sampel & $10^{-1}$ & $\begin{array}{c}\text { Pengenceran } \\
10^{-2}\end{array}$ & $10^{-3}$ & MPN/ml \\
\hline $\begin{array}{c}\text { Susu bubuk awal } \\
\text { produksi }\end{array}$ & $0 / 3$ & $1 / 3$ & $0 / 3$ & 3 \\
$\begin{array}{c}\text { Penyimpanan Minggu } \\
\text { ke-1 pada suhu ruang }\end{array}$ & $2 / 3$ & $1 / 3$ & $1 / 3$ & 20 \\
$\begin{array}{c}\text { Penyimpanan Minggu } \\
\text { ke-1 pada suhu } \\
\text { refrigerator }\end{array}$ & $1 / 3$ & $1 / 3$ & $1 / 3$ & 11 \\
$\begin{array}{c}\text { Penyimpanan Minggu } \\
\text { ke-4 pada suhu ruang }\end{array}$ & $2 / 3$ & $2 / 3$ & $2 / 3$ & 35 \\
$\begin{array}{c}\text { Penyimpanan Minggu } \\
\text { ke-4 pada suhu } \\
\text { refrigerator }\end{array}$ & $2 / 3$ & $1 / 3$ & $1 / 3$ & 20 \\
\hline
\end{tabular}

Angka MPN pada susu bubuk kambing PE adalah 3 MPN/ml (Tabel 6), dan ini masih dalam kisaran yang diperbolehkan menurut BSN (2006) yaitu maksimal $20 \mathrm{MPN} / \mathrm{ml}$. Tabel 6 juga menunjukkan adanya peningkatan angka MPN selama penyimpanan. Lama penyimpanan berpengaruh terhadap semakin tingginya angka MPN pada produk susu dan penyimpanan suhu ruang berdampak pada angka MPN yang lebih tinggi dibandingkan penyimpanan suhu refrigerator. Hal in berarti bahwa tingkat cemaran mikrobia lebih mudah terjadi ketika susu bubuk disimpan pada suhu ruang dibandingkan pada suhu refrigerator, dengan konsekuensi susu akan lebih mudah rusak. Hasil positif uji penduga coliforms pada penelitian ini mengindikasikan masih rendahnya sanitasi dari proses produksi susu bubuk, salah satunya karena suhu pasteurisasi $72^{\circ} \mathrm{C}$ selama 15 menit masih belum cukup optimal untuk membunuh semua mikrobia pada susu segar kambing PE.

\section{KESIMPULAN}

Teknologi spray drying terbukti efektif untuk menurunkan kadar air susu asal kambing PE sehingga diperoleh susu bubuk asal kambing PE dengan kadar air yang rendah (1,5 sampai 1,7\%). Kualitas fisik susu bubuk kambing PE secara umum masih di bawah kualitas susu bubuk komersial, terutama dalam hal kelarutan dalam air (wettability) dan masih tingginya indeks ketidaklarutan (insolubility index). Kualitas nutrisi susu kambing tidak banyak mengalami kerusakan selama proses pengeringan. Kadar protein susu bubuk yang diperoleh sudah memenuh standar protein susu komersial, namun kadar lemak dan laktosa masih di bawah standar susu komersial. Angka TPC susu bubuk kambing PE masih dalam kisaran Standar Nasional Indonesia (SNI) yaitu di bawah $10^{5} \mathrm{CFU} / \mathrm{g}$, namun tingginya angka EB mengindikasikan rendahnya sanitasi bahan baku dan proses produksi. Hal ini terlihat dari masih tingginya angka coliforms yang berarti bahwa produk susu bubuk berpotensi tercemar oleh E. coli. Penelitian lanjut untuk peningkatan kualitas fisik susu bubuk asal kambing PE khususnya kualitas wettability perlu dilakukan dengan emulsifikasi menggunakan soya lesitin sebagai emulsifier. Peningkatan kualitas nutrisi juga masih perlu dilakukan terutama dengan fortifikasi menggunakan berbagai vitamin dan mineral bubuk. Peningkatan sanitasi bahan baku dan proses produksi perlu dilakukan untuk peningkatan kualitas mikrobiologis dan mencegah kontaminasi patogen pada susu bubuk kambing PE.

\section{UCAPAN TERIMAKASIH}

Penulis mengucapkan terimakasih kepada Direktorat Jenderal Pendidikan Tinggi (Ditjen DIKTI) Kementrian Pendidikan Nasional yang telah mendanai penelitian ini melalui program hibah penelitian strategis nasional (STRANAS) tahun $2010-2011$

\section{DAFTAR PUSTAKA}

Abid H, Ali J, Waqas M, Anwar Y, Ullah J. 2009. Microbial quality assessment study of branded and unbranded milk sold in Peshawar City, Pakistan. Pakistan J Nut 8: 704-709. DOI: 10.3923/pin.2009.704.709.

Adesiyun AA, Stoute S, David B. 2007. Pre-processed bovine milk quality in Trinidad: Prevalence and characteristics of bacterial pathogens and occurrence of antimicrobial residues in milk from collection centres. Food Control 18: 312-320. DOI: 10.1016/i.foodcont.2005.10.012.

Anderson M, Hinds $\mathrm{P}$, Hurditt S, Miller P, McGrowder D, Alexander-Lindo R. 2011. The microbial content of unexpired pasteurized milk from selected supermarkets in a developing country. Asian Pac J Trop Biomed 1: 205-211. DOI: 10.1016/S2221-1691(11)60028-2.

Anema SG, Li Y. 2003a. Association of denaturated whey proteins with caseins micelle in heated reconstituted skim milk and its effect on casein micelle size. J Dairy Res 70: 73-78. DOI: $10.1017 /$ S0022029902005903.

Anema SG, Li Y. 2003b. Effect of $\mathrm{pH}$ on the association of denaturated whey proteins with casein micelles in heated reconstituted skim milk. J Agric Food Chem 51: 1640-1646. DOI: 10.1021/jf025673a.

Anonim. 2011. Water activity in food. http://drinc.ucdavis.edu/ dairysciences.htm [21 Oktober 2011].

[AOAC] Association of Official Analytical Chemists. 1990. Official Methods of Analysis. The $15^{\text {th }}$ Edition. The Association of Official Analytical Chemists. Washington, DC.

Astuti M. 1981. Rancangan Percobaan dan Analisis Statistik. Fakultas Peternakan UGM. Yogyakarta.

[BSN] Badan Standarisasi Nasional. 2006. Standar Nasional Indonesia. 2006. Susu Bubuk, SNI-01-2970-2006. Badan Standarisasi Nasional. Jakarta.

Blodgett R. 2010. Bacteriological analytical manual appendix 2, most probable number from serial dilutions. http://www. 
fda.gov/Food/ScienceResearch/LaboratoryMethods/Bacteri ologicalAnalyticalManualBAM/ucm109656.htm.

[5 September 2011].

Chatterjee SN, Bhattacharjee I, Chatterjee SK, Chandra G. 2006. Microbiological examination of milk in Tarakeswar, India with special reference to coliforms. African $\mathrm{J}$ Biotechnol 5: 1383-1385.

Cho Y, Singh H, Creamer LK. 2003. Heat-induced interactions of $\beta$-lactoglobulin $A$ and $k$-casein $B$ in a model system. J Dairy Res 70: 61-71. DOl: 10.1017/S0022029902005642.

De Goffau MC, Van Dijl JM, Harmsen HJM. 2011. Microbial growth on the edge of desiccation. Environ Microbiol 13: 2328-2335. DOI: 10.1111/j.1462-2920.2011.02496.x.

EL-zubeir IEM, Ahmed MI. 2007. The hygienic quality of raw milk produced by some dairy farms in Khartoum-Sudan. $\mathrm{J}$ Microbiol 2: 988-991. DOI: 10.3923//m.2007.988.991.

Erdam YK, Yuksel Z. 2005. Sieving effect of heat-denaturated milk proteins during ultrafiltration of skim milk. I. The preliminary approach. J Dairy Sci 88: 1941-1946. DOl: 10.3168/jds.S0022-0302(05)72869-1.

Guyomarc'h F, Law AJR, Dalgleish DG. 2003. Formation of soluble and micelle-bound protein aggregates in heated milk. J Agric Food Chem. 51: 4652-4660. DOI: 10.1021/ if0211783.

Hadiwiyoto S. 1994. Teori dan Prosedur Pengujian Mutu Susu dan Hasil Olahannya. Penerbit Liberty. Yogyakarta

Kagkli DM, Vancanneyt M, Hill C, Vandamme P, Cogan TM. 2007. Enterococcus and Lactobacillus contamination of raw milk in farm dairy environment. Int J Food Microbiol 114: 243-251. DOI: 10.1016/i.jfoodmicro.2006.09.016.

Khalid M, El Khier S, El Gasim AYA. 2009. Quality assessment of milk powders packed in Sudan. Pakistan J of Nut 8: 388391. DOl: 10.3923/pjn.2009.388.391.

Knights M, Garcia GW. 1997. The status and characteristics of the goat (Capra hircus) and its potential role as a significant milk producer in the tropics: A Review. Small Rum Res 26: 203-215. DOl: 10.1016/S0921-4488(96)00977-7.

LeJeune JT, Rajala-Schultz PJ. 2009. Unpasteurized milk: A continued public health threat. Clin Infect Dis 48: 93-100. DOl: 10.1086/595007.

Marwah MP, Suranindyah YY, Murti TW. 2010. Produksi dan komposisi susu kambing peranakan ettawa yang diberi suplemen daun katu (Sauropus androgynus L. Merr) pada awal masa laktasi. Buletin Peternakan 34: 94-102.

Miyamoto Y, Matsumiya K, Kubouchi H, Noda M, Nishimura K, Matsumura Y. 2009. Effects of heating conditions on physicochemical properties of skim milk powder during production process. Food Sci Technol Res 15: 631-638. DOl: 10.3136/str.15.631.

Moelyanto RD, Wiryanta BTW. 2002. Khasiat dan Manfaat Susu Kambing. Agromedia Pustaka, Jakarta.

Oliver SP, Boor KJ, Murphy SC, Murinda SE. 2009. Food safety hazards associated with consumption of raw milk. Foodborne Pathog Dis 6: 793-806. DOI: 10.1089/fpd.2009.0302.
Oliver SP, Jayarao BM, Almeida RA. 2005. Foodborne pathogens in milk and the dairy farm environment: food safety and public health implications. Foodborne Pathog Dis 2: 115-129. DOl: 10.1089/fpd.2005.2.115.

Park YW, Juarez M, Ramos M, Haenlein GFW. 2007. Physicochemical characteristics of goat and sheep milk. Small Rum Res 68: 88-113. DOl: 10.1016/i.smallirumres.2006.09.013.

Pribadiningtyas PA, Suprayogi TH, Sambodo P. 2012. Hubungan antara bobot badan, volume ambing terhadap produksi susu kambing perah laktasi peranakan ettawa. Anim Agric J 1: 99-105.

Rajput IR, Khaskheli M, Kaleri HA, Fazlani SA, Devi K, Khaskheli GB. 2009a. Determination of total, viable cells and Enterobacteriaceae in categorized milk powder. Pakistan J Nut 8: 1493-1496. DOl: 10.3923/pin.2009.1493.1496.

Rajput IR, Khaskheli M, Rao S, Fazlani SA, Shah QA, Khaskheli GB. $2009^{b}$. Microbial quality of formulated infant milk powders. Pakistan J Nut 8: 1665-1670. DOI: 10.3923/pin.2009.1665.1670.

Salman AMA, Hamad IM. 2011. Enumeration and identification of Coliform bacteria from raw milk in Khartoum State, Sudan. J Cell Anim Biol 5: 121-128.

Shojaei ZA, Yadollahi A. 2008. Physicochemical and microbiological quality of raw pasteurized and UHT milks in shops. Asian J Sci Res 1: 532-538. DOI: 10.3923/ajsr.2008. $\underline{532.538 .}$

Smiddy MA, Martin JE, Huppertz T, Kelly AL. 2007. Microbial shelf-life of high pressure-homogenised milk. Int Dairy J 17: 29-32. DOI: 10.1016/ji.idairyj.2006.01.003.

Straley BA, Donaldson SC, Hedge NV, Sawant AA, Srinivasan V, Oliver SP, Jayaro BM. 2006. Public health significance of antimicrobial-resistant gram-negative bacteria in raw bulk tank milk. Foodborne Pathog Dis 3: 222-223. DOI: 10.1089/ fpd.2006.3.222.

Sudarmadji S, Haryono B, Suhardi. 1984. Prosedur Analisa untuk Bahan Makanan dan Pertanian. Penerbit Liberty. Yogyakarta.

Suguna M, Bhat R, Wan Nadiah WA. 2012. Microbiological quality evaluation of goat milk collected from small-scale dairy farms in Penang Island, Malaysia. Int Food Res J 19: 1241-1245.

Sukarini IAM. 2012. Produksi dan komposisi susu kambing peranakan ettawa yang diberi tambahan konsentrat pada awal laktasi. Maj IImiah Peternakan 9: 1-12.

Sukarini IAM. 2006. Produksi dan kualitas air susu kambing peranakan etawah yang diberi tambahan urea molasses blok dan atau dedak padi pada awal laktasi. Anim Prod 8: 196-205.

Sutama IK, Budiarsana IGM, Supriyati, Hastono. 2012. Perlakuan progresteron eksogenus selama bunting untuk meningkatkan produksi susu dan pertumbuhan anak pada kambing peranakan etawah. JITV 17: 83-91.

Utari FD, Prasetiyono BWHE, Muktiani A. 2012. Kualitas ssusu kambing peranakan ettawa yang diberi suplementasi protein 
terproteksi dalam wafer pakan komplit berbasis limbah agroindustri. Anim Agric J 1: 427-441.

Van Kessel JAS, Karns JS, Lombard JE, Kopral CA. 2011. Prevalence of Salmonella enteric, Listeria monocytogenes and Escherichia coli virulence factors in bulk tank milk and in-line filters from U.S. Dairies. J Food Prot 74: 759-768. DOI: $10.4315 / 0362-028 X . J F P-10-423$.

Vasbinder AJ, De Kruif CG. 2003. Casein-whey protein interactions in heated milk: the influence of $\mathrm{pH}$. Int Dairy $\mathrm{J}$ 13: 669-677. DOI: 10.1016/S0958-6946(03)00120-1.
Widodo. 2003. Teknologi Proses Susu Bubuk. Edisi Pertama. Lacticia Press. Yogyakarta.

Yagoub SO, Awadalla NE, El Zubeir IEM. 2005. Incidence of some potential pathogens in raw milk in Khartoum North (Sudan) and their susceptibility to antimicrobial agents. J Anim Vet Adv 4: 341-344.

Zittle CA. 1969. Influence of heat on k-casein: Effect of $\mathrm{as}_{\mathrm{s}^{-}}$ casein and concentratioin of calcium chloride and sodium chloride. J Dairy Sci 52: 1356-1358. DOI: 10.3168/jds. S0022-0302(69)86754-8. 